Sistematic Review

\title{
Sistematik Review : Penanganan Morbus Hansen di Indonesia dari Sektor Keperawatan
}

\author{
(Sistematic Review : Treatment of Morbus Hansen in Indonesia from the Nursing Sector) \\ Andri Setiya Wahyudi., Irfani Zukhrufatul M., Tiyani, Amalia Niswah Q., Mediani \\ Wahyu P.,Hani Salsabila Deva, Benaya Jamaloe, and Ahmad Junaidi \\ Fakultas Keperawatan Universitas Airlangga
}

Alamat Korespondensi : Universitas Airlangga

Kampus C, Jl. Mulyorejo, Surabaya

\begin{abstract}
ABSTRAK
Perawat merupakan salah satu tenaga medis yang dibutuhkan dalam menanggani sebuah kasus terkait suatu penyakit. Salah satunya adalah mengenai kusta. Kusta merupakan penyakit infeksi kronik. Kusta merupakan penyakit kronis yang disebabkan oleh mycobacterium leprae, kusta dapat menyebabkan gangguan kesehatan berupa kecacatan permanen apabila pengobatan tidak ditangani segera. Selain itu, bila tidak ditangani kusta dapat sangat progresif menyebabkan kerusakan pada kulit, saraf-saraf, anggora gerak, dan mata. Indonesia menduduki peringkat ke-3 total kasus baru di seluruh dunia. Dengan latar belakang tersebut artikel ini bertujuan untuk mengetahui peran perawat dalam penangganan kasus kusta di Indonesia untuk menurunkan angka kejadian kusta di Indonesia.

Pencarian literature dilakukan pada artikel yang telah terpublis pada tahun 2011-2020. Pencarian literatur yang digunakan menggunakan kata kunci kusta, penanganan, dan perawat. Penelurusan dilakukan disitus google scholar dan scoopus.

Hasil dari literature ditemukan bahwa peran perawat dalam penangganan kusta di Indonesia adalah sebagai care giver, educator, fasilitator dalam pencarian pengobatan yang tepat. Dimana apabila kasus penderita kusta dapat ditanggani dengan efektif maka angka kejadian kusta juga menurun.

Perawat memiliki peranan penting dalam menurunkan angka kejadian kusta di Indonesia yang menduduki peringkat ketiga dengan kasus penderita kusta terbanyak. Proses keperawatan juga harus dilakukan secara kompleks.
\end{abstract}

\section{ABSTRACT}

A nurse is one of the medical personnel needed to handle a case related to a disease. One of them is about leprosy. Leprosy is a chronic infectious disease. Leprosy is a chronic disease caused by mycobacterium leprae, leprosy can cause health problems in the form of permanent disability, treatment is not immediately. In addition, if it does not support leprosy it can be very progressive causing damage to the skin, nerves, movement organs, and eyes. Indonesia ranks $3 \mathrm{rd}$ in total new cases worldwide. With this background, this article aims to see the role of nurses in leprosy cases in Indonesia to reduce the incidence of leprosy in Indonesia.

The literature search was carried out on articles published in the years 2011-2020. The literature search used the keywords leprosy, treatment, and nurse. The search was conducted on the Google Scholar and Scoopus sites.

The results of the literature found that the role of nurses in leprosy clients in Indonesia is as a care provider, educator, facilitator in seeking the right treatment. Where cases of leprosy sufferers can be handled effectively, the incidence of leprosy also decreases.

Nurses have an important role in reducing the incidence of leprosy in Indonesia, which ranks third with the most cases of leprosy sufferers. The nursing process must also be complex 


\section{PENDAHULUAN}

Kusta merupakan penyakit infeksi kronik yang disebabkan oleh bakteri Mycobacterium leprae, yang berbentuk batang bacillus yang menyerang kulit, saraf perifer, mukosa dari saluran pernapasan bagian atas dan juga mata (Word Health Organization, 2012). Mycobacterium leprae (M. leprae) merupakan sejenis bakteri yang tumbuh dengan lambat. Menurut Departemen Kesehatan RI, bila penyakit Kusta tidak terdiagnosis dan diobati secara dini, maka akan menimbulkan kecacatan menetap. Apabila sudah terjadi cacat, sebagian besar masyarakat dan keluarga akan menjauhi, mengucilkan, mengabaikan penderita sehingga penderita sulit mendapatkan pekerjaan (Garamina, 2015). Hal ini disebabkan karena keluarga dan masyarakat bahkan penderita memiliki pengetahuan yang kurang, pengertian yang salah, dan kepercayaan yang keliru tentang penyakit Kusta dan kecacatan yang ditimbulkannya. Jumlah pendertia kusta dilansir dari data Dukcapil Kemendagri 2020 jumlah ini mengalami kenaikan sebesar $0,71 \%$ dibandingkan tahun 2019 yaitu 134.848.411 jiwa. Disisi lain kasus kejadian kusta di Indonesia juga meningkat Indonesia telah mecapai status eliminasi kusta, yaitu prevalensi kusta $<1$ per 10.000 penduduk $(<10$ per 100.000 penduduk), pada tahun 2020 . Setelah itu Indonesia menurunkan angka kejadian kusta walaupun penurunan tersebut relatif lambat (Kemenkes RI, 2018). Penularan penyakit Kusta masih berlanjut di masyarakat dan kesadaran masyarakat dalam mengenali gejala dini penyakit kusta masih kurang sehingga penderita kusta yang ditemukan seringkali sudah dalam keadaan cacat. Di samping itu, kusta juga bisa ditularkan lewat inhalasi atau menghirup udara. Kusta memerlukan waktu inkubasi yang cukup lama antara 40 hari sampai 40 tahun. Rata-rata membutuhkan 3-5 tahun setelah tertular sampai timbulnya gejala. Gejala utama kusta, yaitu bercak perubahan warna menjadi lebih putih dan lesi di kulit berbentuk benjolan yang tidak hilang setelah beberapa minggu atau lebih. Lesi kuit juga disertai gejala kebas pada bagian tersebut dan kelemahan otot. Penyakit kusta bukanlah penyakit yang menyebabkan kematian yang seketika, seperti penyakit menular lainnya. Melainkan penyakit kronis sehingga menimbulkan masalah kesehatan masyarakat yang sangat kompleks, bukan hanya dari segi medis tetapi juga dari segi mental sosial ekonomi dan budaya penderita. Untuk menurunkan angka kejadian kusta di Indonesia maka peranan tim medis juga sangat diperlukan salah satunya adalah peran perawat hal ini berhubungan dengan perawat merupakan tenaga medis yang lebih banyak berinteraksi dengan pasien. Tingginya angka kecacatan serta dampak yang ditimbulkan oleh kecacatan maka perlu adanya upaya pencegahan dan penanganan yang adekuat (Nur Laili, 2017).

\section{METODE}

Metode penelitian menggunakan metode penelusuran jurnal dengan systematic review. Pencarian literatur yang digunakan menggunakan kata kusta, penanganan, dan perawat. Penelurusan dilakukan disitus google 
scholar dan scoopus. Artikel yang mempunyai kesamaan diambil salah satunya. Pencarian literature dilakukan pada artikel yang telah terpublis pada tahun 2011-2020 dengan minimal 5 literatur.

\section{HASIL DAN PEMBAHASAN}

Berdasarkan sintesis dari sepuluh jurnal yang dianggap sesuai dengan tujuan penelitian kemudian disaring lagi apakah mempunyai judul yang sama apakah tidak. Setelah menemukan Tujuh jurnal yang didapatkan bahwa adanya keterkaitan dengan peran peran perawat dalam penanganan kusta di Indonesia. Setelah mempelajari kualitas 7 artikel diaktegorikan sebagai data tinggi dan kemudian diekstraksi, ekstraksi dilakukan dengan cara menganalisis data berdasarkan nama penulis, judul penulisan, tahun, dan hasil yang didapatkan dalam jurnal yaitu pengelompokan data penting dalam artikel.

\section{PEMBAHASAN}

\subsection{Faktor ResikoKusta}

Dari hasil systemic review oleh Andy Muharry 2014 didapatkan faktor resiko yang berpengaruh terhadap kejadian kusta, meliputi umur, jenis kelamin, pendidikan, pengetahuan, kondisi ekonomi keluarga, riwayat kontak serumah, riwayat kontak tetangga, kebersihan perorangan, kondisi lingkungan fisik rumah dan kepadatan penghuni. Setelah dilakukan penelitian didapatkan hasil kondisi ekonomi dari keluarga dan kebersihan perorangan adalah faktor yang terbukti berpengaruh terhadap kejadian kusta. Sedangkan, faktor umur, jenis kelamin, pendidikan, kontak serumah, kontak tetangga, lingkungan fisik rumah dan kepadatan penghuni terbukti tidak berpengaruh terhadap kejadian kusta. Kondisi ekonomi berkaitan dengan pendapatan keluarga menentukan pemenuhan kebutuhan rumah tangga termasuk kebutuhan yang berkaitan dengan kesehatan. Sedangkan kebersihan perorangan akan menentukan kesehatan orang tersebut (Aprizal et al., 2017).

\subsection{PenangananKusta di Indonesia}

Dari jurnal yang berjudul "Faktor Risiko Penderta Kusta Tipe Multibasiler di RSUD Tugurejo Semarang tahun 2020" menyebutkan bahwa penderita kusta di Indonesia menduduki peringkat ketiga setelah India dan Brazil dengan jumlah kasus terbanyak di dunia. Penderita kusta enggan untuk melakukan pengobatan hal ini menyebabkan keterlambatan diagnosis dikarenakan buruknya stigma social. Apabila kusta dibiarkan tanpa pengobatan yang tepat dapat menimbulkan beberapa dampak diantaranya terjadi disabilitas fisik serta penurunan hidup bagi pasien penderita kusta. Kusta adalah salah satu penyebab umum neuropatiperifer non trauma di dunia yang menyebabkan disabilitas fisik, masalah, serta stigma social. Indonesia telah mencapai status eliminasi kusta, yaitu prevalensi kusta $<1$ per 10.000 penduduk $(<10$ per 100.000 penduduk), pada tahun 2020 . Setelah itu Indonesia menurunkan angka kejadian kusta walaupun penurunan tersebut relative lambat. Angka prevalensi kusta pada tahun 2017 sebesar 0,70 kasus/10.000 penduduk dan angka penemuan kasus baru sebesar 6,08 kasus per 100.000 penduduk. Selain itu, ada beberapa provinsi yang prevalensinya diatas 1 per 10.000 penduduk. 
Angka prevalensi ini belum bias dinyatakan bebas kusta dan mencapai eliminasi sesuai target nasional (Student, 2020).

\subsection{Peran Perawat Terhadap Penurunan} Angka Kejadian Kusta

Penderita morbun hansen (kusta) kerap mendapat stigma yang menyebabkan mereka ditolak ditengah masyaraat. Mendapat stigma dari lingkungan, baik masyarakat maupun keluarga, akibat penyakit kusta yang diderita, tentunya menimbulkan respon bagi klien. Pengalaman pasien penderita kusta dalam pencarian pengobatan adalah keinginan dan motivasi untuk sembuh. Dalam penangganan kusta, perawat berperan penting sebagai care giver, educator, fasilitator dalam pencarian pengobatan yang tepat.

1.3.1. Peran perawat sebagai care giver dengan memberikan pelayanan terhadap penderita kusta dan keluarga dalam bentuk promotif, preventif, kuratif dan rehabilitatif, untuk mencegah terjadinya kecacatan akibat penyakit kusta dan pengadaan penyuluhan untuk menekan angka kejadian penderita kusta (Khoiriyati, 2020). Perawat dalam pelayanankesehatanberfungsisebagai comforter ataupemberi rasa nyaman, protector dan advocate (pelindungdanpembela),

communicator, mediator dan rehabilitator.

1.3.2. Peran perawat sebagai educator

$$
\text { Peran perawat dalam }
$$

kehidupan sehari-hari baik sebagai tenaga kesehatan maupun sebagai warga masyarakat dan bagian dari komunitas, informasi mengenai penyakit kusta selalu disampaikan dan diperluaskan. Memberikan penjelasan secara langsung kepada keluarga dan masyarakat merupakan salah satu cara perawat dalam menjalankan perannya sebagai edukator dan konsultan.

\subsubsection{Fasilitator dalam pencarian} pengobatan yang tepat

Salah satu peran perawat adalah sebagai tempat konseling dapat dijadikan sebagai tempat bertanya oleh individu, keluarga, kelompok maupun masyarakat untuk memecahkan masalah yang dihadapi (Noratikasari et al., 2020). Perawat memberikan dukungan dengan memberikan penjelasan bahwa pasien dengan kusta yang telah mendapatkan pengobatan tidak akan menularkan penyakit ke orang lain. Pasien dengan kusta juga diberi bekal keterampilan agar setelah kembali ke masyarakat dapat kembali beraktifitas.

\section{KESIMPULAN}

Tingginya kasus kusta di Indonesia menyebabkan Indonesia menjadi negara 3 besar dengan tingkat penyakit kusta tertinggi di dunia. Semua ini disebabkan karena kusta masih berlanjut di masyarakat dan kesadaran masyarakat dalam mengenali gejala dini penyakit kusta masih kurang sehingga penderita kusta yang ditemukan seringkali sudah 
dalam keadaan cacat. Maka dari itu peran tenaga kesehatan khususnya perawat sangat penting dalam pencegahan maupun penanganan kusta di Indoensia. Peran perawat dalam penanganan kusta di Indonesia adalah sebagai care giver, educator, fasilitator dalam pencarian pengobatan yang tepat. Dimana apabila kasus penderita kusta dapat ditangani dengan efektif maka angka kejadian kusta juga menurun.

\section{DAFTAR PUSTAKA}

Aprizal, A., Lazuardi, L., \& Soebono, H. (2017). Faktor risiko kejadian kusta. Berita Kedokteran Masyarakat, 33(9), 427. https://doi.org/10.22146/bkm.25569

Garamina, H. J. (2015). Hubungan Pengetahuan dan Sikap Masyarakat Terhadap Stigma Penyakit. J Aromed Unila, 2(3), 326-332.

Kemenkes RI. (2018). Hapuskan Stigma dan Diskriminasi terhadap Kusta. In InfoDatin Pusat Data dan Informasi Kementrian Kesehatan RI (pp. 1-11).

Khoiriyati, D. (2020). Pengaruh teknik relaksasi nafas dalam dan terapi metabolik murottal Al-Qur' an Asupan gizi, status status sindrom pegawai Pengalaman pasien penderita dan kusta dalam pencarian pengobatan di terhadap tekanan darah dan respirasi pada pasien pre operasi Universitas $X:$ studi deskriptif wilayah Pare-Pare Sul-Sel: studi fenomenologi Lepers 'experience in seeking treatment at Pare Pare South Sulawesi: phenomenology Universitas studi deskriptif.

Noratikasari, P. D., Ariyanto, Y., \& Ririanty, M. (2020). Peran Kelompok Perawatan Diri (KPD) dalam Upaya Mencegah Peningkatan Kecacatan pada Penderita Kusta. Jurnal Promosi Kesehatan Indonesia, $\quad 15(1), \quad 22$. https://doi.org/10.14710/jpki.15.1.22-30

Nur Laili, A. F. (2017). Hubungan Dukungan Keluarga Dan Pengetahuan Terhadap Perawatan Diri Penderita Kusta Di Puskesmas Grati Tahun 2016. The Indonesian Journal of Public Health, 12(1), 13. https://doi.org/10.20473/ijph.v12i1.2017. $13-26$

Student, U. (2020).Faktor Risiko Penderita Kusta Tipe Multibasiler Di Rsud Tugurejo Semarang.Diponegoro medical journal. 9, 127-134. 